\title{
POTRET PENDIDIKAN ISLAM: Perspektif Pembaruan Pemikiran dan Gerakan Islam Indonesia Kontemporer
}

\author{
Oleh: Muljono Damopolii
}

\begin{abstract}
Snapshot of Islamic Education in this country can be explained through the historical reality, starting from developmental era to reformation era nowadays. Therefore, Islamic transformation whether thought aspect or movement, which can be understood clearly through explanation about: the first, innovation science epistemology, which emphasizes on religion science and general science have the same embryo is the unity of God. The second, the modern institution especially high education level relating with real institution condition that Islamic education is subordinate. The third, educational contemporary issues that including Islamic education generally.
\end{abstract}

KEYWORDS: Pendidikan, epistemologi, dikotomi, pembaruan

WALAUPUN pendidikan Islam sebagai suatu disiplin ilmu telah diakui menjadi salah satu bidang studi dan telah menarik minat kalangan pembelajar untuk mengkajinya lebih serius, tetapi sebagai sebuah bidang studi yang masih baru tampaknya disiplin ilmu ini belumlah pesat perkembangannya dibandingkan dengan sejumlah bidang studi Islam lainnya. ${ }^{1}$ Walaupun begitu, potret pendidikan Islam sesungguhnya bisa dipaparkan dalam berbagai perspektif, misalnya dari perspektif pembaruan pemikiran dan gerakan Islam Indonesia kontemporer sebagai tampak dalam judul di atas.

Mengingat luasnya bidang kajian yang dicakup oleh pendidikan Islam, maka tulisan ini lebih memfokuskan pembahasan pada isu-isu pendidikan Islam yang terjadi di era reformasi dengan, tentu saja, tidak mengabaikan isu-isu pendidikan Islam yang terjadi sebelum era reformasi terutama dalam kaitannya dengan pasang surut sejarah panjang pendidikan Islam.

Salah satu isu yang mendapatkan momentumnya seiring dengan merebaknya reformasi adalah citra Perguruan Tinggi Islam. Selama ini, kondisi Perguruan Tinggi Islam-paling tidak sebagian besar kalau tidak dapat dikatakan seluruhnya-hingga berakhirnya milenium kedua selalu 
dikesankan sebagai lembaga pendidikan "kelas dua" yang bukan saja tidak memiliki daya saing, tetapi juga tidak marketable lagi. Hal ini ditandai oleh semakin menurunnya raw input (calon mahasiswa) yang memasuki jenis lembaga pendidikan tinggi ini. Itulah sebabnya, tidak berlebihan jika Abuddin Nata menulis bahwa: "Hingga saat ini kondisi Perguruan Tinggi Islam yang berada di bawah naungan Departemen Agama semacam IAIN (Institut Agama Islam Negeri) belum seluruhnya dipandang sejajar dengan Perguruan Tinggi Umum yang berada di bawah naungan Departemen Pendidikan Nasional. Lulusan Perguruan Tinggi Islam masih memiliki keterbatasan peluang dalam memasuki lapangan kerja yang disebabkan karena keahlian yang dimilikinya, yakni hanya ilmu agama Islam". ${ }^{2}$

Relevan dengan pernyataan Nata di atas, perlu pula dicermati gagasan inti yang diangkat dalam salah satu Ujian Komprehensif Program Doktor (S3) Pascasarjana UIN Syarif Hidayatullah Jakarta, bahwa:

Kuliah di perguruan tinggi luar negeri lebih "mudah" dan setelah lulus juga lebih cepat untuk mendapatkan lapangan pekerjaan. Adapun kuliah di perguruan tinggi dalam negeri jauh lebih "sulit" karena terlalu banyak mata kuliah yang tidak jelas relevansinya. Celakanya, setelah lulus pun akhirnya jadi pengangguran. ${ }^{3}$

Jika dilihat dari perspektif pendidikan di Indonesia, maka pernyataan di atas tampak mengandung banyak kebenaran. Itulah sebabnya, pendidikan yang diselenggarakan di Indonesia banyak menuai kritik, bukan saja karena kualitas output pendidikannya yang rendah, tetapi juga karena pendidikan di negeri ini penuh dengan intrik dikotomi antara pendidikan umum dan pendidikan agama. Dikotomi ini tentu saja membawa implikasi yang luas terhadap penyelenggaraan pendidikan secara keseluruhan. Misalnya, konsep sentralisasi pendidikan yang lebih mementingkan aspek stabilitas daripada memberdayakan pendidikan itu sendiri. Oleh karena itu, berbagai usaha pembaruan pendidikan Islam, terutama Pendidikan Tinggi Islam, di Indonesia begitu gencar terasa setelah runtuhnya pemerintahan Orde Baru yang dinilai sentralistik itu.

Untuk melihat bagaimana potret pendidikan Islam di negeri ini, maka realitasnya dapat digambarkan secara singkat mulai dari era prakemerdekaan sampai dengan era reformasi sekarang ini. Setelah itu, barulah dikemukakan bagaimana transformasi pendidikan Islam yang lebih difokuskan pada: 1) pembaruan pemikiran epistemologi keilmuan; 2) pembaruan kelembagaan terutama pada jenjang pendidikan tinggi serta keterkaitannya dengan kondisi riil kelem-bagaan pendidikan Islam yang ada di bawahnya; dan 3) isu-isu kontemporer pendidikan pada umumnya dimana pendidikan Islam termasuk di dalamnya. 


\section{PENDIDIKAN ISLAM DALAM REALITAS}

Perjuangan umat Islam untuk mensejajarkan pendidikan Islam dengan pendidikan umum sebenarnya sudah lama dimulai, tetapi hingga saat ini pendidikan Islam dapat dikatakan masih harus diperjuangkan terus untuk mewujudkan maksud tersebut. Hal ini disebabkan oleh eksistensi pendidikan Islam yang sering kali harus berhadapan dengan negara. Artinya, kebijakan politik pemerintah tentang pendidikan Islam dapat dikatakan tidak kondusif. Pendidikan Islam barulah mendapat perhatian yang cukup signifikan setelah lahirnya Undang-undang Sistem Pendidikan Nasional No. 2 Tahun 1989 dan lebih dikukuhkan lagi oleh lahirnya Undang-undang Republik Indonesia No. 20 Tahun 2003 tentang Sistem Pendidikan Nasional. ${ }^{4}$ Dalam undang-undang yang terakhir ini secara jelas terasa kesan kuat adanya pengakuan pemerintah secara eksplisit terhadap keberadaan lembaga-lembaga pendidikan Islam, mulai dari jenjang taman kanak-kanak sampai dengan jenjang perguruan tinggi. Akan tetapi, pengakuan pemerintah yang lebih bersifat normatif ini masih dicederai oleh tidak berimbangnya alokasi dana pendidikan untuk lembaga pendidikan yang berada di bawah pengelolaan Departemen Agama dibandingkan dengan yang berada di bawah pengelolaan Departemen Pendidikan Nasional. ${ }^{5}$

Jika dilihat dari kebijakan politik pendidikan pemerintahan Indonesia, maka realitas pendidikan Islam dapat dipetakan ke dalam empat periode. Pertama, kebijakan politik pemerintahan pada masa prakemerdekaan; kedua, kebijakan politik pemerintahan Indonesia pada masa Orde Lama; ketiga, kebijakan politik pemerintahan Indonesia pada masa Orde Baru, dan; keempat, kebijakan politik pemerintahan Indonesia pada masa reformasi. ${ }^{6}$

Ciri kebijakan politik pendidikan Islam pada periode pertama ditandai oleh politik diskriminatif yang sangat kental. Hal tersebut terjadi oleh karena pada periode ini, pemerintahan dipegang dan dijalankan oleh kaum penjajah, sehingga perilaku diskriminatif bukan saja ditujukan kepada pendidikan Islam, tetapi juga kepada umat Islam pada umumnya dan rakyat secara keseluruhan. Sudah menjadi stigma umum bahwa negara yang dijajah oleh Belanda selalu terpuruk dalam kebodohan dan keterbelakangan. Hal ini berbeda dengan negara-negara yang dijajah oleh Inggris yang relatif lebih maju dan tercerahkan. ${ }^{7}$ Walaupun begitu, tidak ada satupun negara di dunia ini yang mau dijajah oleh negara lain, termasuk oleh negara Inggris sekalipun. 
Berbeda dengan periode pertama, pada periode kedua yaitu pada masa Orde Lama, pendidikan Islam sudah mulai mendapatkan perhatian, seperti adanya upaya memperbarui dan memperbanyak lembaga pendidikan Islam yang lebih bermutu sejalan dengan tuntutan zaman. Walaupun begitu, upaya tersebut dalam kenyataan tidaklah berjalan mulus. Sebab, ketika itu pemerintah Orde Lama mengakomodasi tiga kekuatan-nasionalis, sekularis-komunis, dan islamis-yang saling tarik menarik dan tentu saja kelompok sekularis-komunis sangat menentang pember-dayaan umat Islam, termasuk pendidikan Islam. ${ }^{8}$ Hal ini logis mengingat idiologi komunis sangat bertentangan dengan idiologi yang dianut oleh kalangan islamis.

Pada periode ketiga, dimulai sejak berkuasanya Orde Baru tahun 1966, umat Islam banyak berharap agar wajah pendidikan Islam mendapat perhatian yang serius. Akan tetapi, harapan ini juga belum terwujud karena banyak kebijakan politik pemerintahan Orde Baru yang terkadang kurang sejalan dengan keinginan umat Islam. Hal ini disebabkan karena pemerintahan Orde Baru terlalu kuat didukung oleh militer yang bekerjasama dengan terknokrat dan birokrat sipil. ${ }^{9}$ Dukungan militer yang terlalu kuat ini menyebabkan pemerintah kurang tertarik memberi perhatian yang memadai terhadap berbagai keinginan umat Islam. Barulah pada awal tahun 1990-an, ketika dukungan militer kepada pemerintah banyak menuai kritik, maka pemerintah pun berpaling kepada umat Islam dengan memberi perhatian signifikan untuk mendapatkan simpati.

Kini, pendidikan Islam telah memasuki periode keempat yang lebih dikenal dengan periode reformasi. Periode ini di antaranya ditandai oleh semakin berkembangnya wacana demokrasi. Sebagai contoh dapat dilihat dari lenyapnya berbagai aturan yang dipandang sangat memasung kebebasan mahasiswa dalam melakukan berbagai kreativitasnya. Mereka dapat merancang berbagai program sesuai dengan aspirasi yang berkembang. Walaupun begitu, harus pula diakui bahwa masih ada sejumlah kebijakan yang pernah diterapkan oleh orde sebelumnya masih belum sepenuhnya dihapus. Sentralisasi pendidikan seperti dalam hal kurikulum, ujian, akreditasi, anggaran, dan berbagai aturan lainnya belum jauh berbeda dengan yang pernah diterapkan oleh Pemerintah Orde Baru. ${ }^{10}$

Secara keseluruhan dapat dikatakan bahwa pendidikan Islam, sepanjang sejarahnya, senantiasa mengalami marginalisasi di masa lalu. Oleh karena itu, diperlukan political will dari pemerintah dan usaha maksimal dari umat Islam sendiri, terutama dari tokoh-tokoh pendidikan Islam, untuk melakukan pembaruan pendidikan Islam, baik dari segi 
epistemologi keilmuannya maupun kelembagaannya tanpa mengenyampingkan komponen-komponen pendidikan Islam lainnya, seperti tujuan, kurikulum, metodologi pengajaran, tenaga kependidikan (guru dan dosen), dan manajemen.

\section{TRANSFORMASI PENDIDIKAN ISLAM}

\section{Pembaruan Epistemologi Keilmuan Pendidikan Islam}

Di masa lalu ada anggapan bahwa ilmu agama dan ilmu umum merupakan dua hal yang dikotomis. Oleh karena itu, keduanya sulit untuk disatukan. Dengan begitu, sebagai implikasinya, lembaga pendidikan umum berdiri di mana-mana dengan gagahnya di negeri ini, sedangkan lembaga pendidikan Islam harus berjuang sedemikian rupa agar bisa eksis secara kualitatif. Sebab, lembaga pendidikan Islam belumlah dianggap sejajar dengan lembaga pendidikan umum.

Berangkat dari pembidangan keilmuan yang sudah baku-ilmu alam, ilmu sosial, dan ilmu humaniora-dipandang perlu menempatkan etika Islam yang bersumber pada nilai-nilai universal Alquran dan hadis Nabi untuk menjiwai seluruh bidang keilmuan tersebut. ${ }^{11}$ Pandangan semacam ini menjadi sangat mungkin dilakukan bila dilihat dari sisi teori perubahan sosial yang lebih dikenal dengan shifting paradigm, yaitu suatu teori yang menjelaskan bahwa hampir semua jenis kegiatan ilmu pengetahuan, baik natural sciences maupun social sciences, bahkan religious sciences, selalu mengalami apa yang disebut dengan shifting paradigm. Yang dimaksud dengan istilah shifting paradigm di sini adalah adanya pergeseran gugusan pemikiran keilmuan yang memungkinkan terjadinya perubahan, pergeseran, perbaikan, perumusan kembali, nasikh-mansukh, serta penyempurnaan rancang bangun epistemologi keilmuan. ${ }^{12}$ Dengan begitu, maka usaha untuk melakukan integrasi ilmu agama dan ilmu umum dalam sebuah lembaga pendidikan secara utuh bukanlah sesuatu yang tabu.

Memadukan ilmu agama dan ilmu umum dalam dinamika pendidikan Islam dimaknai Azyumardi Azra sebagai upaya memberikan pemahaman bahwa pada dasarnya seluruh ilmu itu berasal dari Yang Maha Esa, sedangkan usaha pendalaman dan pengembangan terhadap keduanya merupakan manifestasi ibadah. ${ }^{13}$

Boleh jadi kemunduran pendidikan Islam lebih disebabkan oleh adanya pandangan dikotomis tentang ilmu-ilmu umum dan ilmu-ilmu agama. Padahal jika ditelusuri secara mendalam, Islam sebenarnya tidak mengenal adanya dikotomi tersebut. Pandangan ini sejalan dengan firman Allah dalam QS. al-'Alaq (96): 1-5, sebagai berikut: 


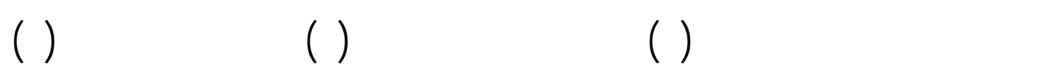

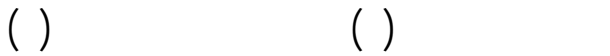

(1) Bacalah dengan (menyebut) nama Tuhanmu Yang Menciptakan, (2) Dia telah menciptakan manusia dari segumpal darah. (3) Bacalah, dan Tuhanmulah Yang Maha Pemurah, (4) Yang mengajar (manusia) dengan perantaraan kalam. (5) Dia mengajarkan kepada manusia apa yang tidak diketahuinya. ${ }^{14}$

Dari ayat di atas dipahami bahwa segala sesuatu yang dikerjakan hendaklah dimulai dengan menyebut nama Allah, sebab inilah yang menjadi kunci, apakah suatu pekerjaan memiliki ruh keislaman atau tidak. Selanjutnya dengan tegas Allah mengatakan bahwa Dia telah mengajarkan kepada manusia apa yang tidak diketahuinya. Di sini Allah tidak membedakan bahwa yang diajarkan-Nya itu adalah ilmu agama atau ilmu umum. Dengan begitu, maka dipahami bahwa asal ilmu, baik ilmu agama maupun ilmu umum, pastilah berasal dari sumber yang satu yaitu Allah. Artinya, kalau umat Islam mau memajukan pendidikan Islam, maka perilaku mendikotomikan ilmu-ilmu agama dan ilmu-ilmu umum haruslah ditinggalkan, karena akan membawa kemunduran bagi umat Islam.

\section{Pembaruan Kelembagaan Pendidikan Islam}

Jika dicermati inti gagasan soal ujian komprehensif program doktor UIN Jakarta seperti dikutip pada awal tulisan ini, maka setidaknya ada empat hal yang dapat ditarik di dalamnya. Pertama, kuliah di perguruan tinggi luar negeri lebih mudah; kedua, lulusan perguruan tinggi luar negeri lebih marketable dalam mendapatkan lapangan pekerjaan; ketiga, kuliah di perguruan tinggi dalam negeri lebih "sulit" karena banyaknya mata kuliah yang tidak relevan; dan keempat, lulusan perguruan tinggi dalam negeri sulit mendapatkan lapangan pekerjaan.

Dengan begitu, disadari bahwa lembaga pendidikan tinggi Islam harus berbena diri dan melakukan transformasi untuk menjawab tantangan zaman yang semakin kompetitif dan kompleks. Perguruan tinggi Islam dianggap tidak marketable lagi dalam menghadapi persaingan global. Boleh jadi, hal ini disebabkan oleh adanya ekspansi pendidikan tinggi umum yang dari dulu lebih mendapat perhatian dari pemerintah dibandingkan pendidikan tinggi agama. ${ }^{15}$ Asumsi ini dapat dikritisi dengan memakai teori Azra tentang pesantren yang mensinyalir bahwa:

Tidak banyak lembaga-lembaga pendidikan tradisional Islam seperti pesantren yang mampu bertahan menghadapi ekspansi sistem pendidikan umum-untuk tidak menyebut sistem pendidikan sekuler. Dengan begitu, 
sebagai konsekuensinya, pertama, pesantren lenyap setelah tergusur oleh sistem pendidikan umum; kedua, pesantren mengalami transformasi menjadi lembaga pendidikan umum; dan ketiga, pesantren setidak-tidaknya menyesuaikan diri dan mengadopsi sedikit banyak isi dan metodologi pendidikan umum. ${ }^{16}$

Apa yang terjadi pada pesantren tradisional seperti sinyalemen Azra di atas tampaknya terjadi pula pada perguruan tinggi Islam. Lahirnya UIN adalah jawaban atas fenomena tersebut, walaupun tidak sedikit umat Islam yang menentangnya karena dianggap akan melemahkan pendidikan Islam itu sendiri. Akan tetapi, pandangan yang terakhir ini dikritisi pula oleh A. Malik Fadjar, bahwa pada tataran normatif-filosofis, pendidikan Islam seringkali hanya terjebak pada perdebatan semantik, apakah menggunakan tarbiyah, $t a^{\prime} d \bar{l} b$, atau $t a^{\prime} l i m$. Bahkan lebih dari itu, pendidikan Islampun sesungguhnya masih terjebak pula pada dikotomi dualisme ilmu-ilmu umum dan ilmu-ilmu agama. ${ }^{17}$ Ini artinya pendidikan Islam akan sulit mencapai kejayaannya kalau mental para pengelolanya (umat Islam) masih berkutat pada hal-hal yang mestinya sudah selesai.

Adanya landasan naqli yang menegaskan bahwa baik ilmu umum maupun ilmu agama berasal dari Tuhan Yang Satu, maka sudah waktunya lembaga pendidikan Islam mendapatkan perhatian yang serius, bukan saja dari pemerintah, tetapi juga dari umat Islam itu sendiri. Kualitas pendidikan Indonesia - termasuk di dalamnya pendidikan Islam - sebagaimana dikutip Suwito dari laporan A. Malik Fadjar, Mendiknas ketika itu, pada Rapat Koordinasi Kesejahteraan Rakyat, tanggal 12 September 2001, pada intinya sepakat dengan laporan The Jakarta Post edisi 3 September 2001. Laporan tersebut menyebutkan hasil penelitian yang dilakukan oleh The Political and Economic Risk Consultancy (PERC) yang berbasis di Hongkong bahwa pendidikan Indonesia berada di urutan ke-12 setelah Vietnam. ${ }^{18}$ Lebih lanjut, Suwito menvisualisasikannya dalam bentuk tabel berikut:

\begin{tabular}{|l|c|l|c|}
\hline \multicolumn{1}{|c|}{ Negara } & Skor & \multicolumn{1}{c|}{ Negara } & Skor \\
\hline 1. Korea Selatan & 3,09 & 7. Malaysia & 4,41 \\
\hline 2. Singapore & 3,19 & 8. Hongkong & 4,72 \\
\hline 3. Jepang & 3,50 & 9. Philipina & 5,47 \\
\hline 4. Taiwan & 3,96 & 10. Thailan & 5,96 \\
\hline 5. India & 4,24 & 11. Vietnam & 6,21 \\
\hline 6. Cina & 4,27 & 12. Indonesia & 6,56 \\
\hline
\end{tabular}

Jika melihat tabel di atas, maka sebagai umat Islam, hatinya pasti merasa miris, mengapa negara yang begitu kaya dan dihuni oleh mayoritas muslim, tetapi pendidikannya begitu tertinggal, bukan saja di tingkat Asia, tetapi di tingkat Asia Tenggara pun, pendidikan bangsa ini masih terpuruk juga. 
Untuk itulah, barangkali perlu disambut positif apa yang disampaikan oleh Suwito dalam pidato pengukuhan guru-besarnya bahwa sikap kritis dan/atau ketidakpuasan dalam dunia pendidikan sangat diperlukan karena sikap serupa ini akan dapat melahirkan keputusan-keputusan atau aksi-aksi baru yang dinilai dapat mengatasi permasalahan yang muncul. Oleh karena menyangkut hidup, maka keputusan atau aksi baru yang ditetapkan tidak dapat dianggap sesuatu yang final. ${ }^{19}$

Lebih lanjut menarik disimak apa yang dikemukakan Suwito tentang potret perjalanan lembaga pendidikan Islam dalam upayanya berbenah diri.

Upaya mengkritisi pesantren tradisional melahirkan pesantren modern. Upaya mengkritisi kedua model pesantren tersebut melahirkan pesantren kilat. Upaya mengkritisi terhadap madrasah tradisional yang hanya mempelajari ilmu-ilmu agama melahirkan madrasah modern yang mempelajari juga ilmu-ilmu umum. Upaya mengkritisi Perguruan Tinggi Agama Islam Negeri (PTAIN) di Yogyakarta dan Akademi Dinas Ilmu Agama (ADIA) di Jakarta, melahirkan Institut Agama Islam Negeri (IAIN) melalui peraturan Presiden No. 11 Tahun 1960. Kritik dan atau ketidakpuasan terhadap IAIN yang menyediakan program studi keagamaan semata, melahirkan IAIN with wider mandate (dengan mandat yang diperluas). Upaya mengkritisi berbagai IAIN cabang melahirkan STAIN. Bisa jadi upaya mengkritisi IAIN with wider mandate akan melahirkan Universitas Islam Negeri (UIN). ${ }^{20}$

Realitas yang disampaikan oleh Suwito di atas mengandung pengertian bahwa sepanjang menyangkut persoalan pendidikan, maka yang terjadi adalah perubahan atau penyempurnaan secara terus menerus. Tidak boleh ada keputusan final yang menyebabkan dunia pendidikan menjadi stagnan apalagi jumud. Inilah mungkin yang disebut oleh A. Malik Fadjar sebagai "mimpi-mimpi besar" yang sebaiknya menjadi obsesi semua akademisi. Ketika pidato pengukuhan guru besar tersebut disampaikan oleh Prof. Dr. Suwito, M.A. pada tanggal 3 Januari 2002, keinginan untuk menjadi UIN Jakarta barangkali masih menjadi mimpi besar, tetapi hari ini, mimpi besar tersebut telah menjadi kenyataan. Universitas Islam Negeri (UIN) Jakarta telah menjadi perguruan tinggi Islam bergengsi (the most competitive university) yang sangat layak disejajarkan dengan perguruan tinggi umum yang telah lebih dahulu ada.

Hal di atas diakui oleh Nata bahwa di bawah kepemimpinan Azyumardi Azra sebagai rektor, citra Universitas Islam Negeri (UIN) Syarif Hidayatullah Jakarta sebagai representasi perguruan tinggi Islam telah berhasil disejajarkan dengan perguruan tinggi umum yang berada di bawah naungan Departemen Pendidikan Nasional. Bahkan kini, UIN yang dipimpin Azra ini diakui sebagai universitas Islam terbaik di Asia 
Tenggara. Berbagai komponen pendidikan, mulai dari visi, misi, tujuan, kurikulum, kompetensi dosen, proses belajar mengajar, sarana prasarana, dan sebagainya sudah ditingkatkan menjadi yang bertarap nasional, bahkan internasional. UIN Syarif Hidayatullah Jakarta telah menjadi kebanggaan umat dan bangsa Indonesia. ${ }^{21}$ Walaupun begitu, kemajuan yang dicapai oleh UIN Jakarta ini bukanlah sesuatu yang terjadi secara serta merta, tetapi telah melalui tahapan-tahapan yang penuh dengan perjuangan. Gagasan untuk mengkonversi IAIN menjadi UIN sebenarnya telah lama menjadi wacana, tetapi barulah terlaksana ketika perguruan tinggi Islam ini di bawah kepemimpinan Azyumardi Azra sebagai rektor.

Konversi IAIN/STAIN menjadi UIN dilakukan sebagai respons atas kenyataan bahwa Madrasah Aliyah yang menjadi basis utama pemasok calon mahasiswa ke IAIN/STAIN ternyata bukan lagi Madrasah Aliyah yang kental dengan jurusan agama, melainkan telah menjadi sekolah umum. Jurusan agama masih tetap ada di Madrasah Aliyah, tetapi jumlahnya sudah sangat sedikit. Dengan begitu, bila ada lulusan program studi agama dari IAIN/STAIN boleh jadi tidak dapat ditampung di Madrasah Aliyah karena jurusan agama di lembaga pendidikan tersebut sudah sangat sedikit. Artinya, kompetensi lulusan IAIN/STAIN tidak diperlukan lagi secara masif di Madrasah Aliyah.

Sebuah penelitian yang baru-baru ini dilakukan oleh penulis menemukan bahwa pesantren sebagai lembaga pendidikan Islam yang selama ini paling kental mengakomodasi materi pendidikan agama ternyata tidak lagi berbasis MTs dan MA, tetapi sudah berbasis SMP dan SMU.22 Ini artinya, para alumni dari lembaga pendidikan Islam ini, secara vertikal, tentu membutuhkan lembaga pendidikan tinggi Islam yang tidak hanya berbasis jurusan agama semata, tetapi juga berbasis jurusan ilmu umum.

\section{Isu-isu Kontemporer Pendidikan}

Berbagai isu pendidikan, termasuk di dalamnya pendidikan Islam, dapat dipaparkan sebagai berikut:

\section{Undang-undang Guru dan Dosen}

Pengesahan RUU Guru dan Dosen yang dilakukan dalam sidang paripurna DPR RI tanggal 6 Desember 2005 dimaksudkan untuk memperbaiki wajah pendidikan di Indonesia melalui perbaikan nasib guru dan dosen. Undang-undang ini diperlukan untuk mendorong peningkatan kualitas guru dan dosen, termasuk perlindungan profesi dan kesejahteraannya. ${ }^{23}$ Akan tetapi, setelah disahkan menjadi undang-undang ternyata produk legislasi DPR tersebut tidak serta-merta menjadikan nasib guru dan 
dosen terangkat ekonominya. Sebab, tunjangan model baru bagi guru dan dosen itu akan efektif paling cepat tahun 2007. Hal ini terjadi karena APBN tahun 2006 sudah lebih dahulu disahkan oleh DPR dan di dalamnya belum tercantum tunjangan tersebut. Dalam kaitan ini, berbagai media menyebutkan bahwa tunjangan profesi guru yang sudah tersertifikasi baru akan dibayarkan pada bulan Oktober 2007. Boleh jadi informasi ini ada benarnya, sebab sejumlah aktivitas terkait sertifikasi guru dan dosen ini sudah mulai dilakukan, misalnya: aktivitas pemetaan guru dan dosen untuk menentukan siapa yang lebih dahulu disertifikasi; penyiapan rancangan peraturan pemerintah; dan penyiapan rancangan keputusan menteri yang akan dijadikan sebagai landasan hukum bagi implementasi Undang-undang Guru dan Dosen tersebut.

Ketika Undang-undang Guru dan Dosen tersebut lahir, komunitas guru dan dosen berharap banyak kepada pemerintah untuk segera membuat Peraturan Pemerintah yang mengatur perihal akreditasi, sertifikasi, kualifikasi, tunjangan dan lain-lain, sehingga undang-undang ini menjadi efektif dan bermanfaat bagi guru dan dosen serta memberi implikasi positif bagi dunia pendidikan secara keseluruhan.

Walaupun Undang-undang Guru dan Dosen telah lahir, tetapi masyarakat pendidikan, terutama guru dan dosen yang menjadi fokus undang-undang ini, ternyata justru diperhadapkan kepada persoalan baru yang menjadi kewajiban mereka. Menurut Mendiknas, Bambang Sudibyo, pemerintah memberikan waktu sepuluh tahun mulai 2007 bagi para guru untuk memenuhi persyaratan sertifikasi profesi pendidikan dengan memiliki gelar sarjana serta lulus uji sertifikasi. ${ }^{24}$ Itulah sebabnya, kelahiran Undang-undang Guru dan Dosen yang sudah memasuki tahun kedua itu, hingga saat ini belum juga memberi kesejahteraan kepada guru dan dosen secara nyata.

Jumlah guru di Indonesia yang telah diangkat, baik itu sebagai PNS maupun guru swasta tetap, mencapai 2,7 juta orang. Dari jumlah tersebut baru 570.000 guru yang memiliki ijazah sarjana. Mereka itu pada umumnya guru-guru muda yang baru diangkat. Ini artinya, kurang lebih 2,2 juta guru harus disekolahkan kembali. Hal tersebut bukanlah pekerjaan yang mudah, terutama bagi guru-guru yang tidak tergolong muda lagi dan tinggal di daerah terpencil yang jauh dari pusat pendidikan. Jika selama sepuluh tahun masih ada guru yang tidak memenuhi persyaratan tersebut, maka guru yang bersangkutan harus berhenti mengajar. Alih-alih berharap untuk mendapat kenaikan gaji berlipat, nasib guru malah masih harus diperjuangkan oleh diri mereka sendiri, antara kewajiban beban mengajar dan kewajiban meng-upgrade diri mereka untuk mendapatkan sertifikasi. 
Tunjangan sebesar satu kali gaji pokok, baru akan didapat seorang guru setelah kewajiban kualifikasi dan sertifikasinya terpenuhi. Padahal gaji guru dan dosen yang selama ini berlaku masih tergolong sangat kecil. Sebagai perbandingan, seorang guru di Jepang yang baru diangkat digaji sebesar 200.000 yen atau setara dengan 17 juta rupiah. Bahkan, seorang pengangguran di Belanda diberi tunjangan sebesar 1.800 gulden atau setara dengan 9,1 juta rupiah. ${ }^{25}$ Lalu, bagaimana dengan sistem penggajian guru di Indonesia? Walaupun gaji guru saat ini dinaikkan $300 \%$ masih jauh lebih kecil dibandingkan dengan tunjangan seorang pengangguran di Belanda.

\section{Pesantren dan Terorisme}

Di masa lalu, ketika bangsa ini masih menghadapi penindasan kaum penjajah, pesantren telah memainkan peranan penting berupa menggerakkan, memimpin, dan melakukan perjuangan dalam rangka mengusir kaum penjajah. Seorang pakar sejarah dari Universitas Padjadjaran, Muhammad Mansur Suryanegara, sebagaimana dikutip Ahmad Tafsir, menyatakan bahwa sulit mencari gerakan melawan penjajah di Indonesia yang bukan digerakkan dan dipimpin oleh orang pesantren. ${ }^{26}$ Oleh karena itu, dalam mengisi kemerdekaan ini, pemerintah seringkali menggunakan pesantren untuk melakukan sosialisasi berbagai programnya. Hal ini wajar, sebab pesantren secara riil memang memiliki pengaruh yang sangat kuat terhadap komunitasnya dan masyarakat sekitar. Apalagi institusi pesantren, sebagaimana disinyalir Azra, termasuk salah satu lembaga pendidikan berbasiskan masyarakat (community-based education) yang telah lama diselenggarakan oleh kaum muslimin Indonesia. Hal ini logis, karena pendirian lembaga-lembaga pendidikan itu berkaitan erat dengan motivasi keagamaan untuk menyediakan pendidikan Islam guna mendidik puteraputeri mereka. ${ }^{27}$

Akan tetapi, kontras dengan kenyataan historis di atas, dunia pesantren saat ini sedang menghadapi stigma buruk pasca peristiwa September 11 Attacks. Peristiwa serangan tersebut telah merubah wajah pesantren yang tadinya disanjung menjadi dicurigai karena disinyalir memiliki kontribusi dalam melahirkan patriotisme teroris menyusul maraknya peledakan bom bunuh diri di Indonesia.

Stigmatisasi dunia pesantren seperti itu telah memperburuk wajah pendidikan Islam. Pada umumnya tokoh-tokoh pesantren, seperti ketua MPR, Hidayat Nur Wahid, melakukan protes keras terhadap rencara pemerintah melalui institusi POLRI untuk mengambil sidik jari komunitas santri karena alasan keamanan. ${ }^{28}$ Hal ini telah melukai hati komunitas 
pesantren karena suatu dugaan buruk yang dialamatkan kepada mereka. Padahal dunia pesantren secara institusional menepis keras dugaan bahwa kurikulum yang diajarkan di pesantren mengandung ideologi terorisme. Kalaupun ada pelaku terorisme yang tertangkap dan mengaku memiliki latar belakang pesantren dapat dipastikan bahwa mereka itu telah terkontaminasi dengan lingkungan lain di luar pesantren, bukan karena didikan yang diperolehnya di pesantren.

\section{Lembaga Pendidikan dan Mall}

Subjudul ini kelihatannya tidak memiliki relevansi satu sama lain, tetapi jika ditelaah dari perspektif pendidikan terlihat bahwa kedua variabel tersebut ternyata memiliki kaitan. Maraknya aktivitas pembangunan mall dewasa ini sangat kontras dengan aktivitas pembangunan atau rehabilitasi gedung sekolah. Begitu banyak gedung sekolah atau lembaga pendidikan yang ambruk karena dimakan usia, tetapi tidak mendapatkan perhatian serius dari pihak yang berwenang. Usaha untuk membangun lembaga pendidikan unggulan berjalan sangat lamban, sesuai teori deret hitung, sedangkan pembangunan mall berjalan begitu cepat, sesuai teori deret ukur.

Maraknya pembangunan mall dipastikan akan mendorong masyarakat menjadi sangat konsumtif. Sementara itu, usaha mencerdaskan bangsa melalui lembaga pendidikan unggulan semakin jauh tertinggal. Kenyataan ini sangat menyedihkan masyarakat pendidikan apalagi amanat undangundang agar mengalokasikan APBN dan APBD minimal sebesar $20 \%$ untuk sektor pendidikan masih jauh dari harapan. ${ }^{29}$

\section{Sekolah dan Isu Tukar Guling}

Nasib sekolah seringkali ditimpah isu tukar guling. Sebut saja yang masih hangat di telinga masyarakat adalah kasus tukar guling yang dialami oleh salah satu SMP di bilangan Melawai, Jakarta Selatan. Tindakan Tukar guling yang dilakukan oleh pihak-pihak yang berkepentingan telah membawa segudang permasalahan bagi siswa, orangtua siswa, guru, dan masyarakat pendidikan umumnya.

Demikian pula halnya di kota Makassar, sebagaimana marak diberitakan di media televisi nasional beberapa waktu terakhir ini, Pemkot Makassar berkeinginan kuat untuk melakukan tukar guling salah satu kompleks yang ditempati oleh empat buah Sekolah Dasar di jalan Jenderal Sudirman yang tergolong elit di kota ini. Dikatakan elit, bukan saja karena tempatnya yang strategis, tetapi juga karena kualitas pendidikan di sejumlah SD ini tergolong bagus. 
Niat Pemkot Makassar untuk menukargulingkan kompleks sejumlah SD tersebut spontan saja mendapatkan protes keras dari orangtua murid dalam bentuk unjuk rasa turun ke jalan. Hal ini wajar karena tindakan tukar guling terhadap lembaga pendidikan seperti itu akan mengubah sosio-psikologis para murid dan orangtua mereka serta masyarakat pendidikan pada umumnya yang sudah terlanjur menikmati fasilitas pendidikan yang memiliki image baik.

Sebenarnya argumentasi yang dikemukakan pemerintah untuk sebuah proses tukar guling itu selalu seolah-olah untuk kepentingan masyarakat luas. Akan tetapi, setelah ditelusuri secara serius ternyata yang paling menonjol adalah kepentingan kapitalisasi dari para pelaku tukar guling itu sendiri, baik dari kalangan birokrat maupun pebisnis. Biasanya lokasi sekolah yang hendak ditukar guling itu secara ekonomis memiliki nilai kapital bisnis yang tinggi.

\section{PENUTUP}

Sepanjang sejarahnya, pemikiran dan gerakan pendidikan Islam selalu saja berhadapan dengan berbagai tantangan, tetapi pada saat yang sama senantiasa pula dicari cela untuk mengubah berbagai tantangan tersebut menjadi peluang. Sebagai contoh, ketika pemikiran mengkonversi IAIN menjadi UIN mendapat tantangan yang hampir tidak mungkin ditembus, maka diambillah jalan dengan menjadikan IAIN with wider mandate (IAIN dengan mandat yang diperluas) seperti yang terjadi di UIN Jakarta dan UIN Alauddin Makassar. Dengan begitu, IAIN tidak murni lagi IAIN seperti di masa lalu, tetapi sudah menjadi IAIN transisional yaitu IAIN yang sudah mengakomodasi sejumlah program studi umum. Walaupun begitu belum bisa juga disebut sebagai murni universitas, sebab secara formal masih banyak persyaratan yang belum terpenuhi, terutama Keputusan Presiden.

Setelah perguruan tinggi Islam, seperti IAIN dan STAIN dikonversi menjadi UIN, maka tantangannyapun tentu saja semakin besar pula. Oleh karena itu, untuk menjadikan pendidikan tinggi Islam tetap survive dan kompetitif, maka diperlukan usaha-usaha secara terus menerus antara lain berupa: 1) mencerahkan masyarakat bahwa pendidikan itu adalah tanggung jawab bersama; 2) menyadarkan masyarakat bahwa pendidikan itu adalah investasi; dan 3) membangun sinergi dengan sumber-sumber modal untuk menanamkan modalnya pada sektor pendidikan.

Ketiga usaha di atas mengandung pengertian bahwa pendidikan itu selalu membutuhkan biaya yang tidak sedikit. Oleh karena itu, masyarakat harus dilibatkan secara aktif-partisipatif dalam pengelolaan pendidikan 
secara riil. Itulah sebabnya, akhir-akhir ini dikembangkanlah konsep pendidikan berbasis masyarakat (community-based education).

\section{CATATAN AKHIR:}

1. Abuddin Nata, Tokoh-tokoh Pembaruan Pendidikan Islam di Indonesia, Jakarta: PT. RajaGrafindo Persada, 2005, h. vi.

2. Abuddin Nata, Tokoh-tokoh Pembaruan Pendidikan Islam di Indonesia, h. 392.

3. Lihat lembar soal ujian komprehensif Program Doktor (S3) PPs UIN Syarif Hidayatullah Jakarta, tanggal 2 Mei 2005.

4. Undang-undang Sistem Pendidikan Nasional (UU RI No. 2 Th. 1989) dan Peraturan Pelaksanaannya, cetakan ketiga, Jakarta: Sinar Grafika, 1999; lihat juga Undangundang Rebublik Indonesia No. 20 Tahun 2003 tentang Sistem Pendidikan Nasional (SISDIKNAS), Bandung: Citra Umbara, 2003.

5. Azyumardi Azra, "Masalah dan Kebijakan Pendidikan Islam di Era Otonomi Daerah", Makalah, dipresentasikan pada Konferensi Nasional Manajemen Pendidikan di Hotel Indonesia, Jakarta, 8-10 Agustus 2002, h. 1.

6. Abuddin Nata, Manajemen Pendidikan: Mengatasi Kelemahan Pendidikan Islam di Indonesia, Jakarta: Prenada Media, 2003, h. 11.

7. Abuddin Nata, Manajemen Pendidikan: Mengatasi Kelemahan Pendidikan Islam di Indonesia, h. 12.

8. Abuddin Nata, Manajemen Pendidikan: Mengatasi Kelemahan Pendidikan Islam di Indonesia, 14.

9. Dewi Fortuna Anwar, "Format Politik Orde Baru dan Agenda Pengem-bangan Demokrasi Politik", dalam Syarofin Arba MF., (ed.), Demitologisasi Politik Indonesia Mengusung Elitisme dalam Orde Baru, Jakarta: PT. Pustaka Cidesindo, 1998, h. 4-6.

10. Abuddin Nata, Manajemen Pendidikan: Mengatasi Kelemahan Pendidikan Islam di Indonesia, h. 20.

11. Lihat "Program Pengembangan IAIN Alauddin Makassar menjadi Universitas Islam Negeri (UIN) Alauddin Makassar", Executive Summary, Makassar: IAIN Alauddin Makassar, 2005, h. 4.

12. M. Amin Abdullah, Studi Agama: Normativitas atau Historisitas?, cet. I, Yogyakarta: Pustaka Pelajar, 1996, h. 102.

13. Azyumardi Azra, "Integrasi Ilmu Agama dan Ilmu Umum: Gagasan dan Solusi", Makalah, disampaikan pada acara Studium General di IAIN Alauddin Makassar, 25 Agustus 2004, h. 2.

14. CD Holy Quran, Keluaran Kelima, Versi 6.50 with Indonesian and English Translation oleh Perusahaan Perangkat Lunak "Sakhr", 1997.

15. Sudah tidak asing lagi terdengar di kalangan komunitas perguruan tinggi agama bahwa anggaran yang disediakan oleh pemerintah untuk membiayai IAIN seluruh Indonesia masih lebih sedikit dibandingkan dengan biaya yang disediakan oleh pemerintah untuk satu perguruan tinggi umum, misalnya, Universitas Hasanuddin.

16. Lihat Azyumardi Azra, Pendidikan Islam: Tradisi dan Modernisasi Menuju Milenium Baru, Jakarta: PT Logos Wacana Ilmu, 1999, h. 95. 
17. A. Malik Fadjar, Reorientasi Pendidikan Islam, Jakarta: Fajar Dunia, 1999, h. 79.

18. Suwito, "Pendidikan yang Memberdayakan", Pidato Pengukuhan Guru Besar Sejarah Pemikiran dan Pendidikan Islam, Jakarta: Institut Agama Islam Negeri Syarif Hidayatullah, 2002, h. 7.

19. Suwito, "Pendidikan yang Memberdayakan", Pidato Pengukuhan Guru Besar Sejarah Pemikiran dan Pendidikan Islam, h. 24.

20. Suwito, "Pendidikan yang Memberdayakan", Pidato Pengukuhan Guru Besar Sejarah Pemikiran dan Pendidikan Islam, h. 27.

21. Abuddin Nata, Tokoh-tokoh Pembaruan Pendidikan Islam di Indonesia, h. 392.

22. Lihat Muljono Damopolii, "Corak Pembaruan Pesantren Modern Pendidikan AlQur'an IMMIM Tamalanrea Makassar (Perspektif Komponen Kelembagaan dan Keorganisasian)", Laporan Penelitian, Makassar: UIN Alauddin, 2005, h. 93.

23. Lihat "Undang-undang Guru Disahkan", Harian KOMPAS, 7 Desember 2005, h. 12.

24. Lihat "UU Guru dan Dosen: Diberi Waktu 10 Tahun Dapatkan Sertifikasi", Harian MEDIA INDONESIA, 7 Desember 2005, h. 1.

25. Lihat Ki Supriyoko "UU Guru, antara Hak dan Kewajiban", Harian MEDIA INDONESIA, 6 Desember 2005, h. 16.

26. Ahmad Tafsir, Ilmu Pendidikan dalam Perspektif Islam, cetakan ketiga, Bandung: PT Remaja Rosdakarya, 2000, h. 192.

27. Azyumardi Azra, "Masalah dan Kebijakan Pendidikan Islam di Era Otonomi Daerah", Makalah, h. 5-6.

28. Lihat "Pengambilan Sidik Jari Kontraproduktif", Harian REPUBLIKA, 8 Desember 2005, h. 2.

29. Lihat Undang-undang Rebublik Indonesia No. 20 Tahun 2003 tentang Sistem Pendidikan Nasional (SISDIKNAS), Bandung: Citra Umbara, 2003, h. 31.

\section{DAFTAR PUSTAKA:}

Abdullah, M. Amin, Studi Agama: Normativitas atau Historisitas?, cet. I, Yogyakarta: Pustaka Pelajar, 1996.

Anwar, Dewi Fortuna, "Format Politik Orde Baru dan Agenda Pengem-bangan Demokrasi Politik", dalam Syarofin Arba MF., (ed.), Demitologisasi Politik Indonesia Mengusung Elitisme dalam Orde Baru, Jakarta: PT. Pustaka Cidesindo, 1998.

Azra, Azyumardi, "Integrasi Ilmu Agama dan Ilmu Umum: Gagasan dan Solusi", Makalah, disampaikan pada acara Studium General di IAIN Alauddin Makassar, 25 Agustus 2004.

------, "Masalah dan Kebijakan Pendidikan Islam di Era Otonomi Daerah", Makalah, dipresentasikan pada Konferensi Nasional Manajemen Pendidikan di Hotel Indonesia, Jakarta, 8-10 Agustus 2002.

------, Pendidikan Islam: Tradisi dan Modernisasi Menuju Milenium Baru, Jakarta: PT Logos Wacana Ilmu, 1999.

CD Holy Quran, Keluaran Kelima, Versi 6.50 with Indonesian and English Translation oleh Perusahaan Perangkat Lunak "Sakhr", 1997. 
Damopolii, Muljono, “Corak Pembaruan Pesantren Modern Pendidikan Al-Qur'an IMMIM Tamalanrea Makassar (Perspektif Komponen Kelembagaan dan Keorganisasian)", Laporan Penelitian, Makassar: UIN Alauddin, 2005.

Fadjar, A. Malik, Reorientasi Pendidikan Islam, Jakarta: Fajar Dunia, 1999.

Lembar Soal Ujian Komprehensif Program Doktor (S3) PPs UIN Syarif Hidayatullah Jakarta, tanggal 2 Mei 2005.

Nata, Abuddin, Manajemen Pendidikan: Mengatasi Kelemahan Pendidikan Islam di Indonesia, Jakarta: Prenada Media, 2003.

------, Tokoh-tokoh Pembaruan Pendidikan Islam di Indonesia, Jakarta: PT. RajaGrafindo Persada, 2005.

"Pengambilan Sidik Jari Kontraproduktif", Harian REPUBLIKA, 8 Desember 2005, h. 2.

"Program Pengembangan IAIN Alauddin Makassar menjadi Universitas Islam Negeri (UIN) Alauddin Makassar", Executive Summary, Makassar: IAIN Alauddin Makassar, 2005.

Supriyoko, Ki, "UU Guru, antara Hak dan Kewajiban", Harian MEDIA INDONESIA, 6 Desember 2005.

Suwito, "Pendidikan yang Memberdayakan", Pidato Pengukuhan Guru Besar Sejarah Pemikiran dan Pendidikan Islam, Jakarta: Institut Agama Islam Negeri Syarif Hidayatullah, 2002.

Tafsir, Ahmad, Ilmu Pendidikan dalam Perspektif Islam, cetakan ketiga, Bandung: PT Remaja Rosdakarya, 2000.

“Undang-undang Guru Disahkan", Harian KOMPAS, 7 Desember 2005.

Undang-undang Rebublik Indonesia No. 20 Tahun 2003 tentang Sistem Pendidikan Nasional (SISDIKNAS), Bandung: Citra Umbara, 2003.

Undang-undang Rebublik Indonesia No. 20 Tahun 2003 tentang Sistem Pendidikan Nasional (SISDIKNAS), Bandung: Citra Umbara, 2003.

Undang-undang Sistem Pendidikan Nasional (UU RI No. 2 Th. 1989) dan Peraturan Pelaksanaannya, cetakan ketiga, Jakarta: Sinar Grafika, 1999.

"UU Guru dan Dosen: Diberi Waktu 10 Tahun Dapatkan Sertifikasi", Harian MEDIA INDONESIA, 7 Desember 2005. 